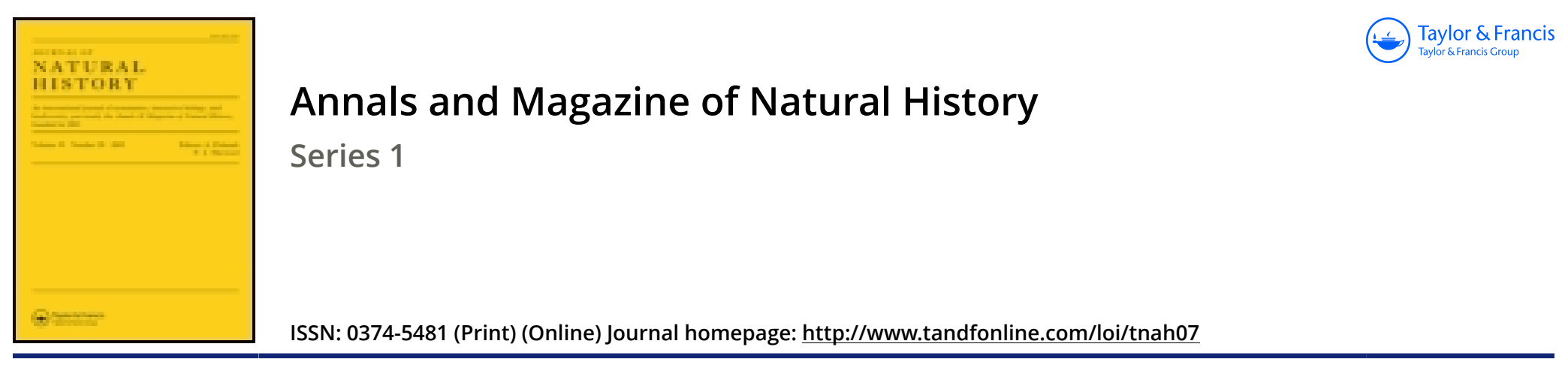

\title{
XLVII.-Observations on several British fishes, including the description of a new species
}

\section{William Thompson Esq.}

To cite this article: William Thompson Esq. (1839) XLVII._Observations on several British fishes, including the description of a new species, Annals and Magazine of Natural History, 2:12, 402-423, DOI: 10.1080/00222933909512421

To link to this article: http://dx.doi.org/10.1080/00222933909512421

册 Published online: 15 Mar 2010.

Submit your article to this journal $₫$

Џll Article views: 1

Q View related articles $๘$ 
abundant base in some of the other vegetable tissues, it was probable that this salt was sulphate of potassa. On comparing the form of microscopic crystals of sulphate of potassa with that of the crystals derived from the pollen, it was found that they were identical; but in order to determine this point with greater certainty, a solution of oxalic acid was added to the pollenic crystals, which upon evaporation afforded crystals having the characteristic form of the binoxalate of potassa (fig. 14.). That the potassa existed in the state of carbonate became probable from the fact, that the water in which the pollen had been macerated did not yield crystals upon a partial evaporation, the carbonate of potassa being deliquescent.

Note.-Although the main object of this communication has been anticipated by $M$. Fritzsche, of whose labours, published in the Transactions of the Petersburgh Academy, our correspondent seems to have had no knowledge, it will prove interesting to many of our readers, inasmuch as the writings of Fritzsche are little known in this country, and his views are in some degree confirmed by the observations of our correspondent, both agreeing in their deductions. M. Fritzsche has not only discovered a third tunic, but even a fourth, which is said to occur, among other plants, in Clarkia elegans, some species of Enothera, and in Encharidium concinnu.-EDIт.

XLVII.-Observations on several British Fishes, including the description of a New Species. By William Thompson, Esq., Vice-President of the Natural History Society of Belfast*.

[With a Plate.]

1. On the British Species of the Genus Monochirus, Cuw.

Bx the kindness of Dr. Parnell in supplying me with specimens of the Red-backed Flounder of Hanmer, 'Pennant's Brit. Zool.', (v. iii. p. 313. pl.48. ed. 1812,) and the Mon. minutus, Parn., I am enabled to speak decidedly on some points which, in my previous remarks on these species, 'Annals Nat.

* Read before this Society December 5, 1838, and illustrated by the specimens of which it treated. 
Hist.,' vol. ii. p. 19, could only, from a want of specimens, be treated of problematically. This I now proceed to do as supplementary to what appeared in the 'Annals;' but it may be well, in the first place, to give a slight sketch of the British Monochiri, in so far as our present knowledge extends.

The first British Monochirus I am aware of being noticed, is that figured under the name of Variegated Sole in 'Donovan's British Fishes,' (pl. 117,) the individual represented having been purchased in the London market in April 1807, but where captured is not mentioned. In the edition of Pennant's 'British Zoology' published in 1812, Mr. Hanmer figured and described a species by the appellation of Redbacked Flounder, and stated it to be "common in the spring upon the coast near Plymouth." In the sixth volume of the 'Magazine of Natural History,' p. 530, a specimen of "Solea variegata" is noticed by $\mathrm{Dr}$. Scouler to have been taken at Rothsay in the isle of Bute. Mr. Jenyns, in his 'Manual of British Vertebrate Animals,' p. 468, takes his description from one procured at Weymouth; and Mr. Yarrell, in his ' History of British Fishes,' v. ii. p. 262, figures and describes an individual supplied from Cornwall by Mr. Couch, and mentions, in addition, from the MS. of Montagu, that this naturalist received a specimen 9 inches in length from $D$ r. Leach, who purchased it with two others in Plymouth market in August 1808. Thus far our authors, with the exception of Mr. Jenyns, (who leaves it to be proved by future investigation whether there be not a second species,) speak only of one Monochirus.

In the first volume of the 'Magazine of Zoology and Botany' p. 526, Dr. Parnell described a Monockirus, which is taken at Brixham, under the specific name of minutus, introducing it doubtfully as a new species, but with certainty as distinct from the "red-backed Sole, Mon. Lingula," and, as such, an addition to the British Fauna. Jastly, the September number of the 'Annals' contains observations by myself on two species of Monochirus taken on the coast of Ireland.

To attempt placing the species, of which notices are here brought together, in a clearer light, is the object of the present communication; and although this may to a certain ex- 
tent be done, the sequel will show that it cannot be performed effectively.

First:-the Variegated Sole as figured and described by Donovan and Yarrell, the specimen recorded by Dr. Scouler*, and the individual noticed by myself under the name of Solea variegata, are identical. The localities in which this species has been procured, are the coasts of Cornwall in England, of the island of Bute in Scotland, and of Down in Ireland. As suggested in my previous paper on this subject, it may be worthy of investigation, whether the Mon. Pegusa of Risso, obtained from the Mediterranean, be this species, ( $t$. iii. p. 258.f. 33. ed. 1826) †. Of the references in Mr. Yarrell's work, those relating to Rondeletius, Willughby and Cuvier apply, I conceive, to the species next to be noticed; Duhamel I have not for consultation; Fleming merely quotes Donovan and Pennant.

Spec. cirar. Mon. variegatus. Pectoral fin about $\frac{1}{4}$ the length of head: scales on lateral line about 85 ; dorsal and anal unconnected with caudal fin.

Secondly:-the Solea Lingula of Jenyns's 'Manual,' (excepting the short specific characters and colours which are copied from Hanmer,) the Mon. minutus of Parnell, and the "Solea Lingula, Rond.,' (Mon. linguatulus) described by me in the 'Annals,' are the same species;-of the identity of these two last I judge from a comparison of specimens. Being of opinion that Mr. Jenyns's description, so far as taken from the individual before him, related to this species; and that, rather than describe the colours from a specimen preserved in spirits, he had copied them from Hanmer's description of the Red-backed Flounder, believing it the same, though it is in reality a distinct species; I communicated with him on the subject, and his reply confirmed my views. The opportunity of examining specimens of this latter fish, which Mr. Jenyns had not, but through the kindness of Dr. Parnell

* As this fish is very briefly noticed in the Magazine, I wrote to Dr. Scouler respecting it, and was informed in reply that it may be considered identical with the Variegated Sole of Yarrell.

+ The large size of the pectoral fin, as represented in the figure, marks a Solea rather than a Monochirus; but it is described as the latter by Risso, and the figure referred to as such by Cuvier, Règ. An., t. ii. p. 343, 2nd ed. 
I have had, could alone have settled this point, the describer of it having been silent on such characters as the length of the pectoral fins, and number of scales on the lateral line, by which chiefly it is distinguished from the present species.

This is, I consider, the Solea parva sive Lingula described and figured by Rondeletius, and again repeated in the works of Gesner (lib. iv. p. 669.), Aldrovandus (p. 237.) and Willughby (p. 102. pl. F. 8. f. 1.). With reference to this, the following note on three specimens obtained since the publication of my paper in the ' $\Lambda$ nnals' may be here given. Of these, which are from 3 to $3 \frac{1}{2}$ inches in length, one has the outline of Solea vulgaris; but the other two differ much from it in being narrower, and tapering more towards the tail, thus precisely resembling, even to the turn of the caudal fin, the Solea parva sive Lingula as represented by these authors: the lateral line too approximates the form given in the figure of this species, but in the specimens is placed rather higher on the body; in these it originates considerably above the middle, and for some way slopes gradually downwards, until it takes a course midway between the dorsal and ventral profile*. A figure of this fish illustrates Dr. Parnell's paper before referred to in the first volume of the 'Magazine of Zoology and Botany.'

The two localities in which this species has occurred in England are southern: at Weymouth in Dorsetshire, whence the single specimen was obtained that served for Mr. Jenyns's description; and at Brixham on the adjoining coast of Devonshire, where, Dr. Parnell informs us, it is taken in the trawl-nets throughout the year. In Ireland it has been procured with the trawl or dredge both in the north and south; in the month of August in the open sea off Dundrum, county of Down; in June and October within the entrance to Belfast bay, and at Youghal in the county of Cork. (See Annals, loc. cit.) Of its occurrence in Scotland I have not seen any record. This is described to be a Mediterranean species.

Spec. Char. Mon. linguatulus. Upper pectoral fin about

* These specimens may further be described as of a red lish-brown colour, minutely freckled over with a darker shade, and having the roundish spots of dark brown and of white on the lateral line and on the body some way inwards from the base of the dorsal and anal tins, as had the individuals obtained in June last. See Aunals, vol. ii. 1. 21. 
one-seventh the length of head; scales on lateral line about 70; an occasional black ray throughout the dorsal and anal fins, this colour not spreading over the adjoining membrane.

Thus far all seems clear, the British specimens recorded being allocated under the two species just treated of, with the exception of Hanmer's Red-backed Flounder obtained at Plymouth, and Montagu's specimen from the same locality. All that is wanted to fix the species of the first-mentioned is an examination of a moderate-sized Mon. variegatus. This Mr. Yarrell possesses; and now supplying him with the specimens by which $I$ arrived at the above conclusions, I leave this point to be determined in the forthcoming Supplement to his 'History of British Fishes.' As all the British Monochiri and Solece are taken on the southern coast of England, it signifies little to which of the species Montagu's specimen belonged.

It may not be useless to mention some of the comparative differences between Hanmer's Red-backed Flounder, (of which two specimens, procured by Dr. Parnell at Brixham*, are now before me,) the Mon. linguatulus and Mon. variegatus. From the $M$. linguatulus it is at once seen to be specifically different, by the greater length of its pectoral fin, (about $\frac{1}{4}$ that of head, whereas it is about one-seventh in the other,) by its smaller scales (about 85 in the lateral line, the other having about 70), and by the conspicuous blotches of black, of which part is on the dorsal and anal fins, and part on the body of the specimens $\dagger$. With $M$. variegatus the Red-backed Flounder accords in the length of pectoral fins, the number of scales on the lateral line, and in general form; in every character indeed, so far as I can judge from comparison with a specimen of $M$. variegatus under three inches in length, except in colour. This difference, in itself certainly not specific, is nevertheless very striking; my specimen of $M$. variegatus, $2 \frac{3}{4}$ inches long, Mr. Yarrell's 5 inches, and Donovan's 9 inches

- It was between these or similar specimens that Dr. Parnell, calling them Mon. Lingula, clearly showed the characters in which they differed from his Mon. minutus. See Mag. of Zool. and Bot., vol. i. p. 528.

+ The black spots mentioned in my description of the colours of Sol. Lingula, Rond. (Annals, loc. cit.), differ entirely from these by appearing on the body only; they are small roundish spots, generally about a line in diameter. 
in length, all presenting similar variegated markings. The colour of the upper side of Hanmer's fish is described to be "a very light brown tinged with red," and is figured of a uniform colour. Such Dr. Parnell's (preserved dry) likewise are, becoming darker at the margin, over which the black blotches on the dorsal and anal fins occasionally extend for a few lines: this marking, as represented in Hanmer's figure, is characteristic of that in the specimens at present under examination; but these exhibit rather more black on the dorsal fin. Hanmer's specimen was $6 \frac{3}{4}$ inches long, Dr. Parnell's are $7 \frac{1}{4}$ and $8 \frac{3}{4}$ inches.

The number of denticles and form of the scales of the Monochiri will not prove to be a positive character, though, relatively considered, they may be of service in the elucidation of species. On examining one of my specimens of $\boldsymbol{M}$. linguatulus as to the number of these denticles, $I$ found that a scale taken from the lateral line had 21 ; another from the next row had 22 and 2 rudimentary points; a third from an adjacent part of the body had likewise 22. The outline of these scales was different, the first being conspicuously contracted about the middle at one side, and straight throughout the other; the second slightly contracted about the middle on both sides, and the third with the sides quite straight. In each of two scales taken from the lateral line of Dr. Parnell's specimen of $M$. minutus there are 22 large strong denticles, with rudimentary points between them: outline of these scales different, and as in the individual just described. In my specimen of $M$. variegatus, two scales which touched upon the lateral line exhibited only 10 and 13 points; but this paucity may be owing to its diminutive size. A scale from the lateral line of Dr. Parnell's smaller specimen of the Red-backed Flounder exhibited 19 denticles, one off the third row from it 18. The form of scale in all the individuals examined is much the same, being broader for its length than that of scales I took from Solea vulgaris; they were generally, but not always, contracted about the middle, either at one or both sides. The sca'es were all examined separately under the microscope, and hence is a different result in the number of denticles from what would have appeared, had they been reckoned on the body of the fish. 
11. Description of a minute Fish allied to the Ciliata glauca, Couch, and Gadus argenteolus, Mont. Plate XVI. figs. 1,2,3.

When dredging in Strangford Lough, county of Down, on the 2nd of July last, at from one to three quarters of a mile off the shore, and the water from ten to twenty fathoms in depth, I for upwards of an hour remarked some very minute fishes coming singly to the surface. They ascended in a somewhat vertical direction, remained but momentarily there, and again, generally in a similar manner, descended until lost to view. Their back appeared to be of a dark colour, but their sides presented the brilliancy of the brightest silver. Their size was rather under an inch; their motion, though somewhat wriggling, surprisingly rapid; so much so, that although the boat was scarcely moving, and the sea quite calm, their continuance at the surface was so short, that the greatest activity had to be exerted to secure them. For this purpose a small canvas net, otherwise used in the capture of minute Medusa, was available. When brought into the boat, they at first sight called to mind the Ciliata glauca and Gadus argenteolus; but the great size of the ventral fins, which were likewise of a pitchy blackness for nearly the last third of their length, seemed opposed to their identity with these species. The boatmen who accompanied me had not observed this fish. before, nor had they heard anything of it.

Desc.-General form elongate; belly protuberant. On a close examination of all the specimens, nine in number, no cirri can with a high power of lens, or on the field of the microscope, be detected on either jaw. The largest individual, $10 \frac{\mathrm{I}}{2}$ lines in length, may be characterised as having the upper jaw the longer; strong and pointed teeth in both jaws; head occupying rather more than $\frac{1}{4}$ of the entire length: eye equal in diameter to $\frac{1}{3}$ rd the length of head: opercle rounded at the base, altogether forming a portion of a circle : first dorsal fin originating just over the opercle, so sunken, and its rays (which are thick and blunt) so short, as to be hardly distinguishable in the profile of the fish, not less than 25 rays; second dorsal commencing close to the first, and before the end of the pectorals, of unequal height, extending to the base of the caudal, not less than 50 rays : pectoral fins rather less than $\frac{1}{5}$ th of the entire length, of moderate size and rounded, placed very high, somewhat above the 


$$
\left(\begin{array}{l}
1 \\
1
\end{array}\right.
$$


opercle, about 20 rays; ventrals placed high, commencing rather in advance of the pectorals, somewhat square at the end, occupying $\frac{1}{4}$ of the entire length, reaching to the vent, and consisting of about 6 rays : anal fin commencing at the vent, and extending to the base of the caudal, unequal in height, having at least 40 rays : caudal fin elongate, occupying $\frac{1}{5}$ th of the entire length (measured from last vertebra of body), somewhat rounded at the end, containing about 30 rays*: branchial rays about 7 : vent midway between snout and base of caudal fin. CoLour when recent - : back, rich green varied with dots of gold and black: operculum, entire sides and under surface bright silver; pectoral, dorsal, anal and caudal fins uniformly of a pale colour, ventrals likewise so for $\frac{2}{3}$ rds from the base, remainder pitch black; irides silvery.

Since the above was written, I have been favoured by $\mathrm{Mr}$. Yarrell with original specimens of Ciliata glauca, obtained from Mr. Couch, and from these the Strangford species differs as follows. My specimens, under 11 lines in length, do not, like the Cornwall fish-which is 1 inch 5 lines long-exhibit cirri on either jaw. The ventral fins in mine are equal to $\frac{1}{4}$ th of the entire length, in the English specimen to about $\frac{1}{7}$ th; in the latter the longest rays have a fibrous termination, (to the extreme of which the length of the fin was estimated, whereas these fins are somewhat square at the end in the Strangford specimens; besides, they are in these of a pitchy blackness for the last third of their length, although in the other of a uniform pale colour throughout. These differences were likewise constant in Cornwall and Strangford specimens of similar length.

On placing the authentic Ciliata glauca and a Motella quinquecirrata $\uparrow$ of equal size together, the difference is very great;

* Although the number of rays in the fins cannot be given with certainty, an approximation to it has been thought better than entire silence on the subject.

$\uparrow$ One of the two individuals which, judging from their agreement with the characters assigned to C. glauca, were noticed as such in the Annals for September last (́). 14), at which time I had not seen authentic specimens. In colour there certainly was a want of uniformity with the description; but it was considered that this might have been changed by the preserving liquor. Compared with the figures of Couch and Yarrell, (chiefly owing to their being uncoloured,) no obvious difference appeared. By the accompanying coloured figures, though taken from specimens long preserved in spirits, $i$ have endeavoured to show this difference; in such small representations it is almost impossible to give more than the general aspect of the fish. 
the dull hue of the latter presenting quite a contrast to the colour of the other, which is of as brilliant a silver as any of the Clupeiade. Its general organization too is much more delicate than that of the Motella: in the form of the head they are different; in C. glauca, the separating line between the opercle and pre-opercle, both of which are silvery and somewhat hard, is conspicuously marked; in the Motella the opercle appears exteriorly undivided, in consequence of its soft and fleshy covering. The snout of C. glauca is shorter than that of the other, and the mouth smaller; this is differently formed from that either of a Motella or Clupea, but possesses numerous sharp and curved teeth along both jaws. Its rictus is in a line with the first third of the eye ; that of the $M$. quinquecirrata with its posterior margin. No pores are apparent within the posterior line of the opercle, as in the species just named, but a row of them surmounting the upper lip. The difference in the ventral profile is considerable, all the specimens of $C^{\prime}$. glauca being, from the protuberance of the belly, very convex anteriorly,-an appearance which the Motella does not present.

When announcing this species in the "Magazine of Natural History,' (vol. v. p. 15) Mr. Couch founded a new genus upon it, which he called Ciliata; but subsequently, in the works of Mr. Jenyns and Mr. Yarrell, it appeared as a Motella. Although its possessing the very few characters assigned to this genus may be considered sufficient to place this fish under it, the comparison of specimens, of which the result has been given, induces me to think that it should constitute a new genus. It participates in the characters both of Clupea and Motella, resembling the former in its silvery brilliancy*, and in almost instantly dying ou removal from the water (which the latter genus can long survive): its form, posterior to the head, is precisely that of Motella, with which it likewise accords in possessing cirri. In selecting a generic name, that of Ciliata should, by reason of its priority, be adopted, were it not pre-engaged + . Such being the case, I propose,

* It has a metallic appearance, as if covered with silver-leaf, wholly unlike the silvery whiteness of the lower portion of the body in some of the Gadida, as Gad. minutus, Merlangus vulgaris, \&c.

+ Ciliés, which may, I think, be considered equivalent to Ciliata, though 
as a compliment well merited by Mr. Couch for his practical knowledge of fishes, that the genus be named after him, Couchia. To the Strangford species the name of minor may be given.

Generic characters.-CovchIA. Body elongate, compressed posteriorly: first dorsal fin, like that of Motella, very low, composed of soft rays unconnected by a membrane: pectorals and ventrals placed high: second dorsal and anal fin long: divisions of opercle well defined exteriorly.

Specific characters.-Couchia minor. (Plate XVI. fig. 1.) Lesser Mackerel Midge. Upper jaw the longer : ventrals long (from $\frac{1}{4}$ to $\frac{1}{5}$ th the length of head), and black at their termination: sides silvery*.

The Gadus argenteolus (Pl. XVI. fig. 2.) of Montagu 'Wern Mem.', v. ii. p. 449. must be adverted to in connexion with the present species. By its describer, it is stated to be " nearly allied to the three-bearded Cod, Gadus Mustela, in most particulars; but the shape of the head and the colour t are essentially different." It was the striking dissimilarity presented by a comparison of specimens of C. glauca and Mot. quinquecirrata in these very characters, that led me to re-separate them generically; and consequently the C. glauca and G. argenteolus may, from agreement in these points, be in the first place regarded of the same genus $\$$ as here defined. On

I know not whether this term itself has been used, appears, from Jourdan's 'Dict. des Termes,' \&c., to have been adopted in a somewhat similar sense by four different authors.

* The absence of cirri is not given as a character, as better vision than mine may yet detect them.

$\dagger$ The name of Whitebait (Clupea alba), which Montagu mentions as applied to the $G$. argenteolus by the fishermen, however erroneously, is suffciently indicative of its Clupea-like aspect.

‡ Montagu remarks of the $G$. argenteolus, that "the whole fish is of a silvery resplendence except the back, which is blue changeable to dark green;" and that the three-bearded Cod he has "taken of all sizes, from the most minute to its full growth of 16 or 17 inches, and never observed it to vary in colour, except as it grows large it becomes more rufous, and throws out spots, which is never observed till it exceeds 6 or 7 inches, but is invariably rufous-brown in its infant state." As a general description, this is equally applicable to the five-bearded Cod (Mot. quinquecirrata), of which I have however taken spotted examples smaller than has been just noticed. Specimens now before me of different sizes, from $1 \frac{1}{4}$ to $5 \frac{1}{2}$ inches in length, are of a tolerably uniform brown colour on the head, back, sides and fins, varied only in the larger individuals by yellowish white at the an- 
looking critically to the detailed description of $G$. argenteolus (fig. 2.), and applying it to the authentic specimen of C. glauca, Pl. XVI. fig. 3, there is, with one exception, such a similarity in every character which may be comprised under form and colour, that I am fully persuaded they constitute but one species. The single discrepancy, like to a specific one, is that of three cirri only being attributed to G.argenteolus; but as it is much more easy to overlook two than to distinguish all the cirri*, I cannot under the circumstances, and at the same time not forgetting Montagu's great accuracy in description, consider this alone a sufficient reason for separation. The localities too, in which only theG. argenteolus and C. glauca are hitherto recorded to have occurred, tend further to favour this view; by Montagu the first mentioned was obtained on the south coast of Devonshire, where it has not since been observed; but by Mr. Couch the latter was some time afterwards procured on the adjoining shores of Cornwall. It is in the present communication that the range of this genus is for the first time shown to extend beyond the south-west of England. Finally, with a full belief of the identity of Montagu's and Couch's fishes, although they have hitherto been regarded by naturalists without any specific reference to each other, I would suggest that the name applied by the former author should be retained, and that Couchia argenteola be applied to the species.

Specific characters.-Couchia argenteola. Upper jaw the longer, 5 cirri, four on the upper, one on the lower jaw : ventrals moderate (from $\frac{1}{6}$ to $\frac{1}{7}$ the length of head), and of a whitish colour: sides silvery.

terior part of the under surface of the body, and in the smaller by the white extending to the lower portion of the opercle, and here, as well as beneath, faintly tinged with silver.

* As before stated, cirri could not be detected in any of the Strangford specimens: lest this should be owing to want of discrimination on my own part, they were submitted to two scientific friends who are well accustomed to the use of the microscope; but neither could they detect any cirri under it, nor with the aid of a lens: the specimens, it must be remembered, were small. It is only by very close examination that four cirri can be perceived on the upper jaw of the large Lnglish C. glauca. "Cirri three, two before the nostrils and one on the skin," are Montagu's words, leaving us in doubt on which jaw he perceived the third cirrus. 
In. On the identity of the Trigla Cuculus, Bl., with the T. Gurnardus of authors; together with Observations on two Species of the Genus Gobius.

When noticing the $T$. Cuculus as an addition to the Fauna of Ireland, in the first volume of the 'Annals'* (p. 348), I embraced the opportunity of offering some remarks on the confusion that existed about the species. In so far, the observations then made may not be useless; but as it was looked upon in the ordinary light of being a species distinct from T. Gurnardus, of which it has very recently been shown to be merely the young, I feel that a few notes are requisite as supplementary.

In a paper on some species of British fishes read by Dr. Parnell before the meeting of the British Association at Newcastle, the author stated that an examination of a series of specimens, embracing all sizes, had led him to the conclusion that T. Cuculus, Bl., (T. Blochii, Yarr.) is only the young of T. Gurnardus; and to him alone, I believe, is this highly interesting discovery due, for such, in consequence of the manner in which it is effected, I conceive it to be $\dagger$. Having lately procured a series of specimens, that I might, for my own satisfaction, examine into this question, I shall here give the results. The following extract from the ' Histoire Naturelle des Poissons' of Cuvier and Valenciennes, by whom they are considered as distinct species, may in the first place be desirable. "Leur tête est la même, ses granulations sont semblables, les dentelures des lobes de leur museau sont tout

* One oversight was here committed. Mr. Jenyns is mentioned in company with other authors as not having described the relative length of the first and second rays of the first $D$. fin to each other; but although this is not alluded to in his ' Manual ' under the head of $T$. Cuculus (a circumstance which led to the remark), the relative differences only between this species and T. Gurnardus being described, rendered any observation on this point unnecessary, when a similarity was considered to prevail in this character. For a similar reason Cuv. and Val. did not particularize the relative length of these rays.

$t$ In the number of specimens of each species, independently of the beautiful manner in which they are preserved, Dr. Parnell's collection of British fishes stands quite unrivalled. In these Trigle is a notable instance of the advantage of a series of different sizes, the young and old fish being so different, that without having traced the changes from youth upwards, we could hardly believe in the modification which really takes place. 
aussi distinctes, et les points de leurs pièces operculaires et de leur épaule tout aussi aiguës; mais les trois premières épines de leur dorsale n'ont pas, comme dans le gurnard gris, les côtés granulés ou chagrinés : on ne voit qu'une dentelure à peine perceptible sur le tranchant antérieur des deux premières. Les crêtes des écailles qui garnissent leur fossette dorsale sont entières et sans crénelures, et se terminent chacune par une simple pointe. Celles des écailles de leur ligne latérale ne sont pas non plus crénelées comme dans les gurnards gris, mais ont deux à trois dents de scie, dont une est plus saillante et plus aiguë que les autres. Tout le reste est parfaitement conformé de même dans les deux espèces."Article T. Cuculus, tome iv. p. 68.

\section{T. Cuculus.}

No. $1 .=2 \frac{1}{2}$ inches long. Colour red, "with a conspicuous black spot on the upper part of the first dorsal," extending from the 3rd to the 5 th ray. A few denticles on the 1 st D. ray only; all the scales on the $D$. ridge entire, each being a sharp spine directed backwards; scales of the lateral line not crenated, but consisting of a series of hooked spines similarly directed.

Nos. 2. and $3^{*}=3$ and $3 \frac{1}{2}$ inches long. Colour red, a conspicuous black spot from 3 rd to 5 th ray of 1 st $D$. fin. Scales of D. ridge and lateral line as in No. 1; no denticles on D. rays in No. 2; the rays in No. 3. imperfect.

\section{Intermediate between T. Cuculus and T. Gurnardus.}

No. 4. $=7$ inches long. Colour dark grey, black spot of 1 st D. fin very conspicuous. Two anterior scales of $D$. ridge slightly denticulated, the remainder simple; scales occupying the anterior part of lateral line for about an inch in extent, crenated; remainder as in Nos. 1.-3.: first D. ray denticulated, and to a greater extent than in No. 1.

No. 5. $=9$ inches long. Male, colour greyish-red, a conspicuous black spot on 1st D. fin. The few anterior scales only of the D. ridge slightly denticulated; anterior portion of every scale on the lateral line crenated, but each terminating in a hooked spine : 1st and 2nd D. rays denticulated, points on the 1 st increasing in number $\uparrow$.

* The specimens described as T. Cuculus in the 'Annals,' vol. i. 348.

+ Since this was procured, Dr. Parnell has faroured me wilh a specimen of similar size, and which, being in the transition state, admirably shows the characters of both species. 


\section{T. Gurnardus.}

No. 6. $=11$ inches long. Female, colour blackish-grey, a black spot on D. fin. Scales on D. ridge all crenated, points directed upwards; those on the lateral line all crenated, occasional scales throughout its length terminating in a hooked spine, 3 anterior $\mathrm{D}$. rays crenated.

No. $7 .=11 \frac{1}{2}$ inches long. Male, colour greyish-red, black spot on 1 st $D$. fin. Scales throughout $D$. ridge crenated, but nearly all of them having the terminal hooked spine; scales on lateral line all crenated, but, as in the D. scales, all except those occupying the anterior inch terminated by a spine; 1 st and 2 nd anterior rays only of 1st $\mathrm{D}$. granulated.

No. $8 .=13 \frac{1}{2}$ inches long. Colour blackish-grey, with a slight tinge of pale-red over it; lst D. fin generally dusky. Scales of D. ridge crenated, all the points directed upwards; scales throughout lateral line crenated, many of them on the hinder $\frac{2}{3}$ rds of its length terminating in a spine; 1 st $3 \mathrm{D}$. rays granulated throughout almost their entire length; 4th and 5th rays partially granulated.

No. $9 .=13 \frac{1}{2}$ inches long. Female, colour dark-grey, varied with yellow; D. fin generally blackish, but of a darker hue where the black spot usually occurs. Scales on D. ridge crenated throughout, points directed upwards; D. scales as in No. 8.; 1st and 2nd D. rays granulated nearly throughout their length, 3 rd and 4 th slightly so about the middle.

No. $10=14$ inches long. Female, colour grey, varied with yellow, Ist D. fin with a black spot. Scales on D. ridge and lateral line as in last, four anterior rays of 1st D. fin conspicuously granulated, 5th partially so about the middle.

No. $11=15$ inches long. Female, colour dark-grey, varied by yellow; 1st D. fin generally, pale dusky*. Scales on D. ridge and lateral line as in last; 3 anterior rays of 1 st D. fin strongly granulated throughont almost their entire length, 4th and 5 th granulated for more than half their length; 6th granulated on one side. No. 6., 11 inches long, was considerably darker in colour than the three last.

Thus the T. Cuculus may be traced gradually passing into the $T$. Gurnardus, until this species appears fully developed. It may further be perceived, that as this fish increases in size, the granulations extend over the rays of the first dorsal fin, and are not confined, as described by authors, to the three or

* The recent colours of all but Nos. 1-3 are here given. 
four anterior ones only. So far as my observation extends, the red colour assigned to the T. Cuculus is not peculiar to the species at any age; and individuals of this hue may be looked upon as occasional varieties :-from $2 \frac{1}{2}$ up to $12 \frac{1}{2} *$ inches in length, I have seen specimens of a reddish colour. Considered relatively to the length of body, the pectoral fins are larger in young than in adult individuals; in those of considerable size they often extend so far as to be on a line with the vent.

The Grey Gurnard, commonly known by the name of knoud in the north, is a common species on the Irish coast: specimens from the northern, eastern, and southern shores are in my possession. It is chiefly taken in the summer and autumn; to Belfast market it is sometimes brought from the beginning of March until the end of October. Not being in much favour for the table with those who can afford a choice, it becomes a cheap food to the poorer people.

At Dundrum, on the coast of Down, where I have seen it captured, sand-eels and the fat of meat were successfully used as bait; and once, in my presence, a slice taken off the side of one the moment it was brought into the boat, had hardly reached the bottom before another was taken with it; this I learned was a common bait. The food that has generally occurred to me in their stomachs was crustacea and small fishes, chiefly of a silvery colour, as Ammodytes and Clupea. The Grey Gurnard, when taken from the water, emits before dying a kind of snoring noise like others of the genus, and hence the name of Piper bestowed on T. Lyra.

Gobius niger, Cuv. and Val.? and G. Britannicus, Thomp.

When recording a species of Groby in $1837+$ as new to the British Fauna, I stated my opinion, judging merely from description, that it was the species described as G. niger by Cuv.

* This specimen may be described as tinged with red over the ordinary grey colour which appears on the back and upper part of the sides in T. Gurnardus; on the lower part of the sides, and to near the ventral profile, it was of a deep-rose colour; all the fins too had reddish markings.

+ See 'Proceedings of Zonl. Soc. of London,' 1837, p.61. The G. niger, Cuv. and Val. is the addition to the Fauna; Brilannicus is applied to the $G$. niger of Mont., \&c. The reasons for this allocation of names are fully stated in the work just cited, p. 63. 
and Val. 'Hist. des Pois.,' t. xii. p. 9, and that it was at the same time distinct from the G. niger of Montagu 'Yarr. Brit. Fish.,' v. i. p. 252, and Jenyns, and probably from that of Yarrell. Of the former species I had then seen but the one native specimen - captured by myself in the bay of Galwayand therefore it was considered injudicious to draw up the specific characters. Having now obtained from Mr. R. Ball of Dublin two other specimens for examination-from the coasts of Galway and Cork-I can do so with more confidence. Although an easy task to point out the relative differences, it is not so with the absolute characters; these may be described as

G. niger, Cuv. and Val. ?

Teeth on the outer rows of both jaws very much larger than the others, and curving inwards.

Scales small, with long cilia on their free margins.

D. $6-16 ;$ P. 20 ; V. 5 each; A.13; C. 14, and some short.

On comparison, the largest $G$. niger, Cuv. and Val., 3 inches 2 lines long, and the G.Britannicus, 3 inches in length, present the following appearances:-

Viewed from above, the head is more equable in breadth in G. Britannicus; in the other it approaches more to a conical form. When placed on the side, the $G$. niger is rather the deeper, carrying greater breadth to the base of the caudal fin; the scales are much smaller in $G$. niger, yet the cilia on their margins are longer than in the other: from some of the scales being wanting, their number cannot be accurately given; but reckoned from the opercle in a straight line along the middle of the body-for the lateral line is inconspicuous in both species-to the base of the caudal fin, there are about 10 more in G. niger than in G. Britannicus; about 45 in the one, and 55 in the other may be mentioned as an approximation: pecten-like strix $\dagger$ on the scales of both species. In G. niger, the outer row of

* The examination of more specimens has shown that there is but little disparity between these species in the dorsal sulcus and the comparative length of jaws, although a difference did, in these respects, appear in the individuals first compared (See Zool. Proc.). The jaws may in both be called equal. Of four specimens of $G$. niger, one had a more depressed line from the head to the first dorsal, another a broad groove, and the remaining two displayed neither appearance.

t See Cuv. and Val., t. xii. p. 12.

Ann. Nat. Hist. Vol. 2. No.12. Feb. 1839. 
teeth in both jaws is considerably the largest, and they differ entirely in form from those of $G$. Britannicus, this being the most obvious differential character between the species; of the large hooked teeth, there are about 16 in the outer row of each jaw; no teeth apparent either on vomer or tongue*: in addition to the very numerous card-like teeth in both jaws of $G$. Britannicus, the anterior part of the vomer is paved with them; on the tongue none are apparent $\uparrow$. The dorsal fins contiguous in both, the 2nd $D$. is obviously higher than the 1 st in $G$. niger than in $G$. Britannicus, as in the latter the two or three longest rays are equal to the general length of those in the 2nd D., a size which they do not attain in G. niger. In colour these specimens differ considerably, (but in this we need not look for constancy,) the G. niger, from the general blackish or dusky hue of the body and fins, (these much darker than in its congener,) well meriting its specific name: along the base it is of a dull yellow (in other specimens pale lilac-grey): the general hue of the G. Britannicus is much lighter and more varied, the head, body above, and a short way beneath the lateral line marbled with yellow and brown, and points of black scattered along the lateral line; yellowish on the under parts.

Iv. On the identity of Crenilabrus multidentatus, Thomp., and Labrus pusillus, Jenyns: with Notes on the Irish Coregoni.

In the month of June 1837, I with some doubt characterized a Crenilabrus as new, under the specific name of multidentatus (Proc. Zool. Soc., 1837, p. 56), and subsequently gave a more detailed account of it, ' Mag. Zool. and Bot.,' v. ii. p. 449. From the species possessing some of the principal characters of Lab. pusillus, I lately felt desirous of comparing specimens of this fish with mine; and for this purpose $\mathrm{Mr}$. Yarrell very obligingly forwarded to Belfast, for my examination, the only specimen of it he possessed, and which is one of the original individuals described by Mr. Jenyns. A com-

* Cuv. and Val. thus describe the teeth: "Chaque mâchoire a une large bande de dents en crochets, qui dépassent les autres, et dont on compte Is ou 20 à chaque mâchoire," t. xii. p. 10. The similarity in the teeth cbiefly led me to believe this species and mine to be identical.

+ Montagu remarks of the teeth, that "the under jaw is roughened by them like a rasp." Mr. Yarrell describes the lower jaw "with fine cardinglike teeth in several rows" (v. i. p. 253). Mr. Jenyns notes "fine card-like teeth in several rows, the inner rows much smaller than the outer," p. 385 . 
parison of this specimen, $2 \frac{1}{4}$ inches in length, with my own, proved the species to be the same.

It must be stated that $C$. multidentatus was not considered a distinct species, without even critical attention having been given to the description of $L$. pusillus. The following are the chief differences that led to the belief of their non-identity.

C. multidentatus.

"Teeth numerous and large, two rows in the upper, one in the lower jaw, number in lower 26 , outer row of upper jaw $20 *$. Upper jaw the longert.

Colour (in spirits) very pale greenish brown on the back, olivegreen on the sides becoming paler beneath, sides with darker longitudinal bands throughout ; 3 blackish spots, one on the pre-opercle behind and rather below the centre of the eye, a second on the body at the base of the caudal fin and at its lowermost portion, and the third at the base of the last ray of the dorsal fin."
L. pusillus.

"Teeth of moderate size, conical, regular, about 16 or 18 in each jaw.

Jaws equal.

Colour (in spirits) yellowishbrown, with irregular transverse fuscous bands : dorsal irregularly spotted with fuscous: anal light brown; the other fins pale."

Mr. Yarrell's specimen, which is in excellent preservation, has no appearance whatever of transverse fuscous bands, like the individual described by Mr. Jenyns:-it is also free from spots, thus differing again from mine $\ddagger$.

When looking over Mr. R. Ball's collection of native fishes in June last, I had the pleasure of secing among them a Crenilabrus, which accorded better, in some respects, with $\mathrm{Mr}$. Jenyns' description of $L$. pusillus than the smaller specimens, and, compared with them, differed in several points of view to be hereafter noticed.

* My specimens, with the teeth more numerous, were nearly one-half smaller than the one which (from the length of 4 inches being assigned to the species) I presumed served for Mr. Jenyns' description.

- + 'The difference in the length of jaws is very trivial.

+ See an excellent figure in the Mag. Zool. and Bot., vol. ii. pl. 13, to which draughtsman and engraver did equal justice. 
This individual-4 inches 11 lines in length-is larger than any of this species recorded in the "Manual of British Vertebrate Ani'mals.' Excepting that the ascending margin of the pre-opercle is not " very oblique," it agrees with the specific characters there attributed to that species, and generally with the detailed description of dimensions. So far as the brief description of colours in the 'Manual ' enables a judgement to be formed, there is a similarity between them. The specimen before me (preserved in spirits) presents considerable variety of colours. Two-thirds of the upper portion of the sides and entire body, from origin of anal to base of caudal fin, of a pale but rich brownish-red, with faint indications of several transverse dusky bands ; remainder of anterior portion to ventral profile, yellowish-grey. Head variously coloured in stripes, \&c., somewhat in the manner of Labrus variegatus, Gmel., and others of the Labridce; iris bright red, lips orange; dorsal fin pale, varied with red and dusky tints; of this latter colour from the first to between the third and fourth rays: a black spot, partly on the body and partly on the base of the two last rays terminating this fin: pectorals reddish, with a black band at the outer base of the rays (similar to that in the variety of Crenilabrus Tinca called C. Cornubiensis): ventrals pale, with reddish markings: anal fin with faint dusky and reddish markings alternating : caudal fin pale dusky, irregularly tinged with a reddish colour.

D. $19+11$ (last double); A. $3+9 ;$ P. $14 ;$ V. $1+5 ;$ C. 13 or 14 conspicuous (21 altogether) $=\mathrm{Br} .5$.

This individual has the ascending line of the pre-opercle less oblique than the smaller specimens; the teeth, instead of the uniformity of arrangement described in C. multidentatus, increasing somewhat gradually in size towards the centre, 21 in the lower, and a similar number in the outer row of upper jaw; a dark brown marking appears down the centre of many of them; those of the other individuals are uniformly transparent. Scales three or four fewer in number on the lateral line in the large specimen than in the others, and the tubular projections on those throughout it less developed; in it likewise the concentric stria of the scales are less strongly marked, and the lineated appearance (produced by the strice of each scale being more deeply cut along the centre than elsewhere) less apparent than in the others. The colour already described is very different from that of the smaller specimens. This individual, as well as those described as C. multidentatus, was obtained at Youghal. 


\section{Coregonus clupeoides, Nilss.? Plate XVI. fig. 4.}

By the continued kind attention of the Rev. C. Mayne (Vicar-general of Cashel), a second specimen of this fish, taken in the river Shannon near Killaloe, was forwarded to me on the 9th of November last. This individual, being quite perfect, enables me now to supply a figure of the species, and to offer some further remarks upon it. On comparing it in every character with my description of the individual first obtained 'Annals' for Dec., p. 267, which was divested of its scales, and injured in some of the fins, I find very few additional observations to be requisite. Its length is $4 \frac{3}{4}$ inches, depth $10 \frac{1}{2}$ lines; number of scales on lateral line, and from it to dorsal and ventral profile as described in last, judging in that instance from their impressions merely; the scales rounded at the posterior margin, and smaller than in any other British Coregonus. D. 14 ; P. $16 ;$ V. $1+11$; A. 14? C. $20 \frac{1}{1} \frac{2}{2}=$ Br. 9. In the dorsal, the 4th and 5 th rays longest, and of about equal length; the few anterior rays of the pectorals about equal, the 1st much the stoutest; 4th and 5th longest in the anal, and about equal; axillary scale of ventrals rather more than one-third their length. Colour of specimen (from spirits); body above lateral line and a short way below it pale yellowish-olive when viewed in the shade, but with the light striking on it, of a delicate silvery blue, thence to the belly silvery; dorsal and caudal fins marked over the rays and membrane with black points, imparting to them, when closed, a blackish tinge; pectorals, ventrals, and anal, excepting a very ferv black points on last, colourless.

It is desirable to institute a comparison of the chief differences between this species and Cor. Willughbeii, the only other British fish of the genus having the lower jaw exceeding the upper in length. The C. clupeoides differs from this in the mouth being less obliquely cleft, or in having the lower jaw less ascending (when the mouth of $C$. Willughbeii is closed, the point of the lower jaw is so elevated as to be on a line with the upper margin of the pupil of the eye; in the other it is on a line with the centre of the pupil); opercle broader and less rounded off at the base, and with the ascending mar- 
gin more oblique in C.clupeoides*; its scales very much smaller; outline of dorsal fin very different, the membrane in this falling considerably short of the points of the rays, and its outline from the longest ray to the extremity of the fin being somewhat rounded. This comparison was made between two specimens of $C$. clupeoides? from 4 to 5 inches in length, and two of C. Willughbeii about 6 inches long.

From the continental species, Cor. Marcenula, as described by Bloch, (and which, like the C. Willughbeii, agrees with that under consideration in the lower jaw being the longer, the C. clupeoides differs chiefly in having a greater number of rays in the dorsal fin (14 or 15 to 10 ), in having teeth in the under jaw, (on this difference alone I should not lay any stress, the teeth being so small as to be easily overlooked,) and in the negative character of wanting such an appearance on the lateral line as would come under the description of "garnie de cinquante-huit point noirs:" the scales on the back and greater part of the sides are dotted with very minute black points visible under a lens, and of which those on the lateral line have share, but not so many as the row just above, the number of these points gradually decreasing from the back downwards.

Should this fish eventually prove to be distinct from the C. clupeoides of Nilsson, I would suggest that the specific name of elegans be applied to it.

\section{Coregonus Pollan. Plate XVI. fig. 5.}

In connexion with the figure of C. Pollan now given to accompany that of Cor. clupeoides, the following remarks are offered. The characters in which the Pollan differed from the two British species known at the time it was announced, were pointed out in the original description. From the two species since recorded, it may in the first place be stated to differ from C. microcephalus, the Loch Lomond fish, in having the head longer, the fins less, (and of a lighter colour,) and the scales rather smaller; from the C. clupeoides the Pollan

* The difference in this respect between these two species is not greater than we sometimes see in different sexes of the same species of Salmo: the Coregoni not having been dissected, their sexes are unknown to ne. 
differs in being much larger, in the jaws being equal $*$, the scales rather larger and in the form of the dorsal fin. (See accompanying figures.)

Of a female Pollan, $11 \frac{3}{4}$ inches in length, procured from Lough Neagh on the 28th of November last, the entire weight was $9 \mathrm{oz}$, that of the ova subsequently extracted $2 \mathrm{oz}$. 3 drachms; of this, which was just ready for exclusion, I had a drachm weighed, and reckoned the number of ova it contained; taking for granted that this would be alike in each drachm throughout the whole, (and from the uniform size of the ova, each a line in diameter, there can be very little difference,) the number of ova altogether would be 6156 . This too I should consider about the average produce of the species, as the specimen was of ordinary size, and contained a similar quantity of ova with several others dissected at the same time. Of the stomachs, \&c. of twelve Pollans examined on this occasion, the greater number were empty, but two or three contained minute Entomostraca, two Pisidia, and a Limneus pereger-this last was three lines in length.

Jan. 1, 1839. I received from the Rev. C. Mayne a fullgrown specimen of the Cor. Pollan, taken near Killaloe, either on the river Shannon or its expansion, Lough Derg.

\section{REFERENCES TO PLATE XVI.}

Fig. 1. Couchia minor. Fig. 2. Couchia argenteola. Fig. 3. Couchia glauca. Fig. 4. Coregonus clupeoides. Fig. 5. Coregonus Pollan.

* This seems to be the best general character; I have seen some individuals with the upper rather exceeding the lower jaw, others with the lower slightly projecting beyond the upper, and the difference was not sexual. It is perhaps unnecessary to observe, as it would apply to fishes generally, that other individuals examined vary much in relative proportions from those which served for the original description : the proportion of head to depth of body, it is obvious, must vary in the sexes at particular periods; that of head to entire length I have found to be as 1 to 5 , as well as " 1 to $3 \frac{1}{2}$," and the vertebræ 60 . The two following characters were before unnoticed: axillary scale of ventral fins about one-third their length-about 84 scales on the lateral line : this is the number attributed by Dr. Parnell to both of the Loch Lomond Coregoni; in a specimen of one of these, C. microcephalus, under 10 inches in length, (much less than the size they attain,) with which I have been favoured by its describer, there are but 76 ? scales on this line. This induced me to examine various sized Pollans, to see whether there might be any difference in this respect, when none appeared in the individuals inspected, which were from $9 \frac{1}{2}$ to 13 inches in length. 